Viso - Cadernos de estética aplicada

Revista eletrônica de estética

ISSN 1981-4062

No 8, jan-jun/2010

http://www.revistaviso.com.br/
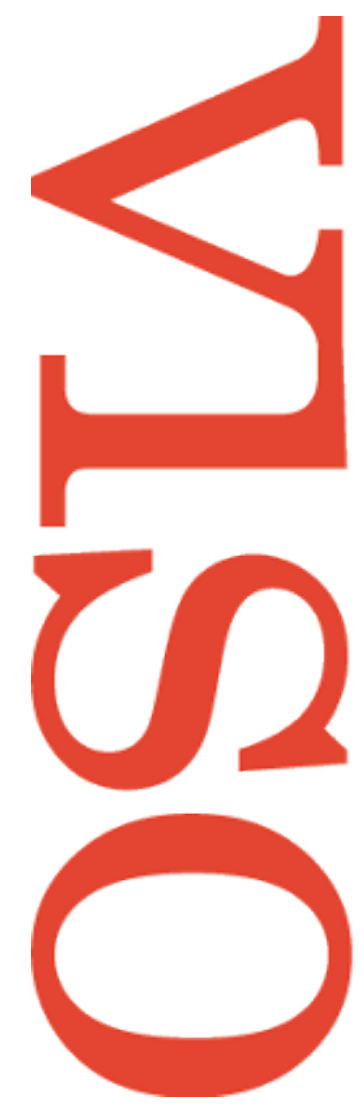

\title{
Estética como fisiologia aplicada em Nietzsche
} Renato Nunes Bittencourt 


\section{RESUMO}

\section{Estética como fisiologia aplicada em Nietzsche}

A proposta deste artigo consiste em pensarmos a relação intrínseca que Nietzsche estabelece entre a estética e a compreensão orgânica da vida humana, associada diretamente a uma perspectiva fisiológica. Cabe ressaltar que a noção de fisiologia em Nietzsche não se fundamenta em parâmetros puramente biológicos ou materiais, mas envolve todos os atos criativos do indivíduo. Por conseguinte, para compreendermos de forma precisa a realização da criatividade artística é de suma importância que se faça valer a importância da fisiologia do artista no processo de elaboração da obra de arte. Onde os instintos vitais se encontram em declínio existencial, haverá uma obra de arte decadente; onde os instintos vitais manifestam exuberância, capacidade de assimilação e saúde, haverá uma glorificação da existência através da arte.

Palavras-chave: Nietzsche - Fisiologia - Organismo - Saúde - Romantismo

\section{ABSTRACT}

\section{Aesthetic as applied physiology in Nietzsche}

The proposal of this article consists in directly thinking the intrinsic relation that Nietzsche establishes between aesthetics and the organic understanding of the human life, associated with a physiological perspective. It is worth mentioning that the notion of physiology in Nietzsche is not based purely on biological or material parameters, but involves all the creative acts of the individual. Therefore, in order to understand the accomplishment of artistic creativity is of utmost importance to stress the importance of the physiology of the artist in the process of elaboration of the work of art. Where the vital instincts are found in existencial decline, there will be a declining work of art; where the vital instincts reveal exuberance, capacity of assimilation and health, there will be glorification of the existence through art.

Keywords: Nietzsche - Physiology - Organism - Health - Romanticism 


\section{BITTENCOURT, R. N. "Estética como fisiologia aplicada em Nietzsche". In: Viso: Cadernos de estética aplicada, v. IV, n. 8 (jan-jun/2010), pp. 121-143.}

DOI: $10.22409 / 1981-4062 / v 8 i / 93$

Aprovado: 02.02.2010. Publicado: 10.07.2010.

(C) 2010 Renato Nunes Bittencourt. Esse documento é distribuído nos termos da licença Creative Commons Atribuição-NãoComercial 4.0 Internacional (CC-BY-NC), que permite, exceto para fins comerciais, copiar e redistribuir o material em qualquer formato ou meio, bem como remixá-lo, transformá-lo ou criar a partir dele, desde que seja dado o devido crédito e indicada a licença sob a qual ele foi originalmente publicado.

Licença: http://creativecommons.org/licenses/by-nc/4.0/deed.pt_BR

Accepted: 02.02.2010. Published: 10.07.2010.

(C) 2010 Renato Nunes Bittencourt. This document is distributed under the terms of a Creative Commons Attribution-NonCommercial 4.0 International license (CC-BY-NC) which allows, except for commercial purposes, to copy and redistribute the material in any medium or format and to remix, transform, and build upon the material, provided the original work is properly cited and states its license.

License: http://creativecommons.org/licenses/by-nc/4.0/ 
O termo "fisiologia" no contexto da filosofia de Nietzsche pode ser compreendido como um processo orgânico do corpo humano que agrega diversas modalidades de expressão nas suas experiências vitais; nessas condições, a noção nietzschiana de "fisiologia" está associada aos processos de assimilação e regulação do organismo como um todo e aos instintos e atividades que potencializam ou diminuem a sua vitalidade, incluindo assim tanto o âmbito "físico" (digestão, circulação sanguínea, ruminação, etc.), quanto o âmbito "psíquico" (os afetos, os instintos, os estímulos nervosos, etc.). A idéia de "fisiologia" em Nietzsche remete, com freqüência, às funções orgânicas ou ao âmbito afetivo no sentido do imediato corpóreo. Dessa maneira, a idéia de atividade fisiológica na perspectiva nietzschiana porta tanto um sentido orgânico/somático como psíquico, tornando tais esferas interdependentes, pois as múltiplas vivências do organismo constituem uma dinâmica indissociável. ${ }^{1}$ Podemos estabelecer uma relação entre a noção de "fisiologia" em Nietzsche e os diversos ramos da cultura, como se cada ato criativo de um indivíduo decorresse diretamente dos processos fisiológicos do organismo. Analisada parcialmente, tal perspectiva poderia parecer redutora, mas, conforme o pensamento nietzschiano, tanto a filosofia como as teorias estéticas, de um modo geral, não foram capazes de compreender o corpo e os seus processos vitais. Dessa maneira, o verdadeiro reducionismo seria deixar de lado o aspecto fisiológico do organismo humano na reflexão filosófica sobre a vida e a criação artística. Enfatizaremos o problema da fisiologia nas suas relações imediatas com a criação artística e na própria filosofia, especialmente as críticas de Nietzsche a Richard Wagner, considerado como o expoente moderno da fraqueza vital na criação artística, assim como ao pensamento platônico, expoente clássico da ascese intelectual, e de que maneira em ambos os casos, conforme a valoração nietzschiana, o problema da decadência vital na cultura, na sociedade e na criação artística pode ser compreendido pelo prisma da "fisiologia": esta se torna o instrumento mais adequado para a análise da existência, pois sua axiologia se baseia em critérios puramente vitais e orgânicos, o que torna a dinâmica corporal o eixo pelo qual se sustentam tanto as valorações como a capacidade de assimilação vital.

Ao dizer que as suas objeções à música de Wagner são fisiológicas, Nietzsche se indaga por qual motivo disfarçá-las em fórmulas estéticas, defendendo assim a insólita tese de que a estética nada mais é do que uma espécie de "fisiologia aplicada". ${ }^{2}$ O que Nietzsche pretende dizer com tal colocação? Certamente que a reflexão sobre os efeitos suscitados pela interação do indivíduo com a obra de arte deve levar em consideração em especial os aspectos que influenciam na ampliação da saúde do corpo e que afetam imediatamente a sua vitalidade intrínseca, seja para melhor ou pior. Afinal, a criação artística genuína, para Nietzsche, envolve a totalidade dos modos de expressão da corporeidade, processo esse que requer a expansão plena da potência vital contida na singularidade do indivíduo capaz de dar vazão aos seus ímpetos criativos. ${ }^{3}$ Rosa Maria Dias destaca que "Nietzsche sente e entende a arte a partir do corpo, pensado como multiplicidade hierarquizada de forças cuja organização é indício de saúde ou doença, de negação ou afirmação da vida". ${ }^{4}$ 
A "fisiologia da arte" pode ser interpretada como uma investigação sobre as motivações psicológicas e orgânicas que influenciam o artista no seu ato criativo, levantando a questão de se porventura o processo de elaboração de uma obra decorre de um transbordamento criativo das suas forças instintivas ou da necessidade de apaziguamento do ânimo mediante o entorpecimento dos sentidos. ${ }^{5}$ Por conseguinte, a compreensão fisiológica da arte requer o uso de um método genealógico das forças vitais que comandam os atos criativos do indivíduo. Mais ainda, a "fisiologia da arte" proposta por Nietzsche enfatiza a recepção da obra de arte no espectador, ou seja, de que maneira a sua afetividade e as suas funções orgânicas são imediatamente influenciadas pela absorção e interação com a criação artística. ${ }^{6}$ Nesse ponto, partilhamos da tese de Müller-Lauter, ao destacar quão longe Nietzsche leva a redução do estético ao âmbito fisiológico. ${ }^{7}$ Podemos constatar que essa perspectiva se sustenta em bases axiológicas imanentes, ao colocar o organismo corporal e as suas funções vitais no centro da reflexão sobre os efeitos da obra de arte nas atividades fisiológicas do ser humano, não levando assim em consideração elementos estranhos ao corpo e aos afetos singulares de um indivíduo.

Certamente um dos aspectos mais fortes desse posicionamento nietzschiano consiste na idéia de que essa concepção se distancia consideravelmente da compreensão de estética tal como preconizada pela tradição filosófica, em especial Kant e Schopenhauer. ${ }^{8}$ Com efeito, Nietzsche critica a perspectiva kantiana de que a contemplação do belo desperta no espectador uma fruição desinteressada. ${ }^{9}$ Ora, se de fato tal experiência ocorresse na práxis criadora, ela denotaria um enfraquecimento das disposições ativas desse indivíduo, mediante a percepção da forma bela. Schopenhauer, por sua vez, considera que a contemplação das formas belas concede ao sujeito cognoscente a possibilidade de sua elevação extática diante das suas condições fenomênicas corriqueiras, estado estético que o libertaria momentaneamente das opressivas cadeias do desejo. ${ }^{10} \mathrm{~A}$ contemplação estética, segundo essa concepção, faria com que o indivíduo obtivesse um lenitivo de sua vontade, libertando-o do jugo do querer e, por conseguinte, do sofrimento. Por esse motivo Schopenhauer considera como degradação estética as obras de arte que retratam corpos nus que evocam situações nitidamente concupiscentes ou mesmo alimentos apetitosos, denominando tal arte como "provocante". ${ }^{11}$ Schopenhauer postula assim a realização de uma contemplação estética desinteressada, atuando como um princípio apaziguador da vontade humana; tal disposição superior se encontra favoravelmente no gênio, aquele que manifesta a capacidade de contemplar intuitivamente as Idéias, isto é, as objetivações imediatas da Vontade, livrando-se das condições empíricas comuns e, por conseguinte, do furor dos desejos e das preocupações mundanas. ${ }^{12}$

Schopenhauer postula uma filiação à teoria do belo em Kant, mas Nietzsche critica veemente tal pretensão, pois na verdade um "interesse" profundo inspiraria a adoração do belo por Schopenhauer, justamente a possibilidade de emancipação estética das dores da existência. Por conseguinte, a relação schopenhaueriana com a beleza é 
plenamente "interessada", mas por uma questão de má-interpretação pessoal tal relação foi escamoteada numa experiência supostamente destituída de querer. De todo modo, a perspectiva de Schopenhauer não descreve de forma objetiva a influência do belo sobre o âmago humano, mas apenas um efeito subjetivo em si mesmo, o apaziguamento existencial da vontade. ${ }^{13}$ Todavia, Nietzsche considera que a contemplação estética e a criação artística pressupõem não o apaziguamento mórbido da atividade do corpo e da afetividade pessoal do esteta, mas a máxima elevação do seu estado de forças vitais. Com efeito, a imagem do belo, ao invés de distrair a mente humana das suas atribulações corriqueiras, alçando-a para a esfera do puro inteligível, proporcionaria na verdade uma embriaguez criativa, diretamente associada ao prazer estético, ao júbilo, à benfazeja saúde. Ao invés de ser um mero calmante afetivo, a arte amplifica os processos vitais do indivíduo, permitindo que ele supere as limitações orgânicas originadas pelos seus estados depressivos e, por conseguinte, as suas atribulações existenciais, tornando-se então mais alegre e mais saudável no âmbito psicofisiológico. Por conseguinte, Nietzsche critica essas tendências estéticas vinculadas ao formalismo teórico e ao âmbito do ascetismo, valorizando, por conseguinte, a expressão artística que preconize o belo enquanto estímulo para a força, para a saúde e para a expansão da capacidade de ação do esteta, aproximando-se da definição do belo segundo a concepção do romancista Stendhal, uma "promessa de felicidade"14, pois a beleza, ao invés de ser uma qualidade estética que, quando contemplada, motivava o apaziguamento do caráter desiderativo da afetividade humana, seria, pelo contrário, um elemento que estimularia o desenvolvimento da vitalidade, de uma sadia sensualidade nas disposições orgânicas do indivíduo. ${ }^{15}$ Se há um efeito "divino" na percepção do belo, ele consistiria em motivar o fortalecimento das disposições fisiológicas de criatividade e atividade daquele que interage com a obra de arte. ${ }^{16}$ Nessas condições, não é indigno da criação artística o seu vínculo com o "interesse", isto é, pela sedução, pela excitação da sensualidade e pelo aumento da capacidade de ação; pelo contrário, é justamente por brotar do âmago do artista e representar os seus ímpetos criativos mais potentes que uma obra de arte obtém o seu valor. Nietzsche coloca como condição fisiológica indispensável para a criação artística a embriaguez, de modo que mais uma vez se demonstra o entrelaçamento entre o impulso estético de criatividade e as atividades orgânicas dos processos vitais do corpo humano, inclusive a energia sexual, da qual decorre o fluxo da força criativa do artista. ${ }^{17}$

Em vista dessas considerações, podemos nos perguntar: o que levaria um pensador a considerar a contemplação estética como um processo no qual se obtém a supressão da sua vitalidade e o apaziguamento da sensualidade? Pensando de acordo com Nietzsche, podemos dizer que essa opção pelo repouso, pela quietude, decorrentes da contemplação da obra de arte, seria expressão de um empobrecimento da vitalidade individual, processo este gerado pelo declínio das condições fisiológicas do organismo. ${ }^{18}$ Ora, um indivíduo que se encontra vitalmente debilitado, organicamente degenerado e incapacitado de digerir satisfatoriamente as suas experiências cotidianas tende a realizar uma interpretação da vida sob a ótica da fraqueza, do empobrecimento das suas forças 
conaturais, prejudicando assim as suas próprias valorações. Do momento em que se considera o afeto, a atividade plural do corpo e os instintos como elementos dignos de desprezo, abre-se espaço para a depreciação das próprias condições da vida, circunstância que revela os sintomas da incapacidade desse tipo de indivíduo de conviver com o próprio fluxo intrínseco de assimilação das suas vivências: o "tipo ressentido", por exemplo, se encaixa nesse perfil, pois sofre de uma incapacidade de "digerir" psiquicamente as suas experiências afetivas. ${ }^{19}$ Essa distorção valorativa pode ser descrita como uma espécie de estranhamento do indivíduo em relação ao caráter dinâmico da vitalidade assimiladora do seu próprio corpo, pois ele não se identifica com as suas particularidades, enaltecendo, isto sim, os seus supostos aspectos "superiores", isto é, os "inteligíveis", como se porventura existisse uma parte do seu "eu" puramente inteligível, superior ao âmbito de sua corporeidade.

Outra questão digna de consideração nessa reflexão acerca de uma compreensão da estética como "ciência" efetivamente associada aos elementos orgânicos da vida humana consiste no fato de que, conforme a perspectiva nietzschiana, Kant e Schopenhauer teriam estabelecido as suas respectivas teorias estéticas pela ótica do espectador, do receptor, concedendo para a atividade artística valorações estranhas à sua dinâmica vital; tais valorações são tipicamente inerentes a quem se encontra fora do âmbito da criação artística. Quem de fato se encontra em condições de tratar de forma adequada da atividade criadora é o próprio artista, pois ele vivencia intrinsecamente a gênese da obra de arte, tal como uma mãe que concebe amorosamente o seu filho e sofre as dores do parto para trazê-lo à luz, numa inefável experiência extática. É por tal circunstância que a definição stendhaliana do "belo como uma promessa de felicidade", de acordo com a interpretação nietzschiana, é muitíssimo mais coerente com o oficio do artista do que as concepções de Kant e de Schopenhauer, pois decorre da experiência de um homem criador, e não de uma teorização estética destituída de uma vivência efetiva como artista. Argumenta Rosa Maria Dias que "Nietzsche não pode admitir a universalidade no domínio da estética. O sem interesse de Kant é para ele signo de um interesse frustrado, de um temor das sensações do corpo". ${ }^{20}$

A aplicação da "fisiologia da arte" na interpretação do sentido da criação estética moderna fará com que Nietzsche direcione grandes críticas a Wagner enquanto musicista, pois o compositor é considerado como um indivíduo que, sofrendo de um malestar em relação ao viver, teria elaborado uma qualidade de música que expressa esse desgosto pela existência terrena e pela energia da saúde, esperando pela redenção espiritual. ${ }^{21}$ Decorreria dessa circunstância a sua adesão a um híbrido ascetismo de bases cristãs entrelaçado a uma interpretação livre do budismo, nomeadamente em Parsifal..$^{22}$ Há que se ressaltar que Wagner jamais deixou de utilizar temas cristãos em suas óperas, e não é tal dispositivo estético que motivaria a repulsa nietzschiana. Com efeito, algumas óperas compostas por Wagner na sua juventude, tais como $O$ navio fantasma, Tannhäuser e Lohengrin - ainda que nos seus respectivos enredos haja o embate íntimo entre a vontade individual e o sentimento de elevação espiritual em prol 
da redenção da existência - possuiriam elementos dramáticos que lhes concederiam qualidades afirmativas, pois os seus protagonistas se singularizam pelo fato de adotarem uma postura de contestação revolucionária contra a mediocridade de espírito dos seus interlocutores e da multidão inconsciente de seu potencial, devido ao cego respeito pelas tradições morais. Por exemplo, em Tannhäuser o personagem-título desafia os costumes do amor cortês ao proclamar a embriaguez do amor afrodisíaco. Mais ainda, em tais narrativas encontramos profundas ressonâncias dos mitos gregos: o Holandês Errante de $O$ navio fantasma se assemelha ao mito de Odisseu que vaga décadas pelos mares em busca de sua terra natal; a proibição de Elsa conhecer o nome de Lohengrin na ópera homônima se aproxima simbolicamente da impossibilidade de Sêmele conhecer a identidade verdadeira de Zeus e, em ambos os casos, a revelação da verdade motiva na vida dessas mulheres terríveis infortúnios. ${ }^{23} \mathrm{O}$ grande problema de Parsifal é que nesta ópera a valoração cristã alcança uma dimensão enfaticamente moralizante e ascética, de modo que não vemos mais o herói revolucionário cuja ação é um atentado contra a hipócrita moralidade incapaz de compreender as aspirações superiores dos homens de gênio, mas justamente a adesão incondicional ao conservador espírito da tradição moral, contra a qual Wagner conflitara ao longo de sua atribulada carreira. Tal como o compositor dissera categoricamente em $A$ arte e a revolução,

o Cristianismo oferece justificação para uma existência miserável dos homens sobre a Terra, destituída de honra e de utilidade. Vai buscar uma tal justificação na maravilha de um amor divino que, ao contrário do que erradamente pensavam os belos gregos, não criou o homem para uma existência terrena de alegria consciente, antes o teria encerrado num catre repugnante, preparando-lhe assim para depois da morte um esplendor eterno de comodidade e inação como recompensa do desprezo de si próprio interiorizado nesta vida. ${ }^{24}$

Entretanto, essa concepção cáustica contra a instituição cristã e seus valores normativos se diluiria através da concepção de Parsifal, a celebração em música do ideal ascético. De acordo com Nietzsche

[...] o Parsifal é uma obra de perfídia, de baixa vingança, que envenena em segredo os frutos da vida. É uma obra ruim. Pregar a castidade é ir contra a natureza. Eu desprezo quem não considera Parsifal como um ultraje dos costumes. ${ }^{25}$

Estudando o conjunto das obras wagnerianas, encontramos a existência contínua de um interessante conflito entre a sensualidade e a castidade, sendo que este embate não manifesta parâmetros excludentes, pois é plenamente possível haver uma sadia disposição sensual convivendo harmoniosamente com a disciplina da castidade. ${ }^{26} \mathrm{O}$ equilíbrio entre essas duas instâncias motivaria o desenvolvimento de uma vida mais jubilosa, inclusive no âmbito das experiências amorosas. Talvez por isso a ópera Tristão e Isolda tenha granjeado a admiração nietzschiana pois, conforme argumenta Iracema Macedo, "Tristão e Isolda não se libertam dos sentidos físicos de uma forma castradora, o que acontece é uma transfiguração do amor físico, uma espécie de sublimação da sensualidade". ${ }^{27}$ Wagner, quando influenciado pelas teorias de Schopenhauer, teria transformado a sua visão de mundo em sentimento afirmativo da vida, no qual os 
protagonistas vislumbram a transformação das dores do mundo através do ato de amor, transfigurando, por conseguinte, as suas individualidades em prol da reintegração cósmica no seio do Uno originário. Mais ainda, Iracema Macedo considera que

Wagner era um schopenhaueriano voltado para o mundo e ele interpretou Schopenhauer à sua maneira. Assumiu a arte como um meio de redenção e emancipação para os homens. O que, para Schopenhauer, era a possibilidade de libertação do indivíduo, para Wagner era a possibilidade de emancipação da sociedade como um todo. ${ }^{28}$

Todavia, nas suas últimas criações, Wagner teria se aproveitado das teorias de Schopenhauer para expressar uma visão de mundo tendenciosamente decadente, entrelaçando esta perspectiva ao espírito cristão, fato este que explicaria a origem do complexo enredo de Parsifal, ao associar símbolos cristãos tradicionais com a idéia de renúncia, castidade e ascese. Ora, em Parsifal, o que predomina da filosofia schopenhaueriana não é mais o recorte criativo operado por Wagner, direcionando o fluxo desconsolado da constatação do sofrimento do mundo para uma busca ascética pelo Nada, como proposto por Schopenhauer, para uma dimensão cosmológica da vida em que através do poder inefável do amor todas as coisas de unificam; pelo contrário, Parsifal encarna justamente a figura do santo ascético delineado por Schopenhauer no livro IV de $\mathrm{O}$ mundo como vontade e como representação. Nietzsche considera que a pregação da castidade é uma incitação pública à antinatureza. Todo o desprezo da vida sexual, toda a sua infecção mediante o conceito de "impuro" é o genuíno pecado contra o espírito santo da vida. ${ }^{29}$

De certa maneira, é apenas no final da vida de Wagner que esse embate se torna irreconciliável, porque adornado com a ênfase decadente do ascetismo e da moral cristã em seus traços mais niilistas. Nesse momento, a aspiração de castidade é revestida com os valores funéreos do ideal ascético em sua vertente mais radical, o passo derradeiro para a negação do corpo e dos instintos vitais. Há que se ressaltar que Nietzsche não considera sintomas de degeneração fisiológica ou disposições antinaturais as práticas de reserva sexual feitas em alguns casos específicos por artistas (e também atletas), quando se encontram em momento de concentração para a realização de uma ação que venha a exigir um razoável acúmulo de forças, pois a atividade sexual libera um grande fluxo de vitalidade, que pode deixar o indivíduo complacente, prejudicando o seu desempenho. ${ }^{30}$ Esclarece Rosa Maria Dias que

o artista é, talvez por natureza, necessariamente sensual, antes de tudo um emotivo, vulnerável em todos os sentidos e induzido naturalmente a experimentar todos os tipos de excitações e sugestões que estas provocam. Apesar disso, no desempenho de sua função, na vontade de alcançar a maestria, é geralmente um homem sóbrio e até casto. É o que exige seu instinto dominante: não lhe permite desperdiçar-se a torto e a direito.

Nessas condições, o grande problema do ascetismo é quando ele se torna um fim em si mesmo, situação que motiva a erupção de estados psicofisiológicos de fraqueza vital, 
que por sua vez influenciarão na criação de valores morais caracterizados pela depreciação da corporeidade. É precisamente um organismo fraco que dependerá da elaboração de parâmetros normativos de conduta para legitimar existencialmente a sua falta de força vital e impor tal penúria a todos os indivíduos que fazem parte desse grupo.

De acordo com a perspectiva nietzschiana, qual seria a motivação para Wagner enfatizar de forma tão veemente essa contraposição a um tipo de existir que agrega consigo mesmo os seus elementos mais antagônicos? Certamente o seu desprezo pela vida, a esperança por uma redenção metafísica, representada através da busca dos seus heróis pela santidade, pela remissão das suas faltas, pela purificação das suas culpas. Uma consciência culpada projetaria na sua criação artística esses valores depreciativos da vitalidade, e o exemplo de Parsifal na cena em que o protagonista, até então um "puro tolo", é seduzido por Kundry, é paradigmático:

Amfortas! / A chaga! — A chaga / Ela arde-me aqui, no flanco!/ Oh! Lamento! Lamento!/ Terrível lamento/ que grita no fundo do coração!/ Oh! — Oh! — / Infeliz! Máximo sofredor!/ Vejo sangrar a chaga:/ sangra agora em mim! —/Aqui — aqui!/ Não! Não! Isto não é a chaga./ Seu sangue corre esvaindo-se em torrentes!/ Aqui! Aqui! O incêndio no coração!/A ânsia, a ânsia terrível/ que domina e oprime todos os meus sentidos!/ Oh! — Tortura de amor! —/Como tudo se arrepia, freme e palpita/em pecaminosa ânsia!.../ Com visão baça, contemplo fixamente o sacro Cálice. -/O Sangue Sagrado arde: -/ A Glória da Redenção, divinamente suave,/ faz vibrar o interior de todas as almas:/ só aqui, no coração, o tormento não cessa./ Ouço o lamento do Salvador,/ O lamento, ah! o lamento!/ por Seu santuário profanado: —/ "Salvai, libertai-me de mãos sujas de culpa!"/ Assim ressoa o Lamento Divino/ Com terrível sonoridade em minha alma./ E eu - o tolo, o covarde,/ em selvagem atitude infantil, fugi!/ Salvador! Redentor! Senhor da Graça!/ Como expiar, eu, pecador, minha culpa?

Desse sistema de declínio e exaustão da vitalidade se originaria a busca por uma dimensão ideal, pela redenção espiritual, pela fuga do mundo, projetando-se numa postulada esfera supra-sensível a possibilidade de se alcançar o fim das contradições existenciais e a autêntica felicidade. Nietzsche apresenta diversas referências ao comportamento de fuga da realidade e busca incondicional pela redenção espiritual nas óperas de Wagner, cujos principais personagens representam claramente esses ideais de submissão aos valores espirituais.

O problema da redenção é sem duvida um problema respeitável. Sobre nenhuma outra coisa Wagner refletiu tão profundamente: sua ópera é a ópera da redenção. Em Wagner, há sempre alguém que deseja ser redimido: ora um homenzinho, ora uma senhorita - este é o problema dele. [...] O navio fantasma prega o sublime ensinamento de que a mulher faz assentar o mais inquieto dos homens, ou, em linguagem wagneriana, o 'redime'. ${ }^{32}$

Ressaltemos que o próprio estilo da música wagneriana também apresentaria, para Nietzsche, sintomas de declínio vital, pois essa arte exige a concentração contínua dos estímulos nervosos do ouvinte, gerando assim contínuos estados de tensão dos nervos. ${ }^{33}$ Mais ainda, Nietzsche considera Wagner uma espécie de feiticeiro dos afetos do ouvinte das suas obras, um manipulador das percepções estéticas do espectador, 
estimulando principalmente o excitamento exagerado dos sentidos. ${ }^{34}$ Conforme comenta Fernando Barros:

Exímio manipulador das excitações nervosas, Wagner teria, segundo Nietzsche, infectado seus ouvintes, de sorte a neles instilar a produção de anticorpos, mas a dependência aos efeitos opiáceos de sua arte. A sedução artística transformar-se-ia, nesse caso, numa inseminação nociva, na administração de um pharmakon que vem à luz sob a forma de poderosas doses de sentimento seguida por uma indefectível hipnose auditiva. ${ }^{35}$

Como podemos compreender essa curiosa perspectiva? Ora, é fato que o compositor, através do seu projeto de renovação artística da cultura européia, representado teoricamente em obras como $A$ arte e a revolução e A obra de arte do futuro, teria elaborado um estilo de composição no qual se exigiria do apreciador a contínua concentração, a fim de que todas as nuances de sua musicalidade fossem percebidas plenamente. Daí o recurso da melodia infinita, que gera a ruptura com a estrutura clássica da divisão da ópera em árias, recitativos, tendência que aliviava os estados de concentração dos ouvintes e lhes permitia realizar atividades estranhas ao ato de contemplação estética. A estrutura da ópera clássica é direcionada para um modelo de espectador que não mantinha um autêntico respeito pela estética musical das representações operísticas, decorrendo dessa circunstância a tendência de muitos compositores, submetidos ao juízo popular, de criarem as suas obras tendo em vista a satisfação desse público ruidoso.

Conforme observa criticamente Wagner, o âmago da arte moderna residia na indústria, a sua finalidade moral era o lucro financeiro e a sua eficácia estética era o entretenimento dos entediados ${ }^{36}$ Comumente um compositor devia aquiescer ao gosto duvidoso da massa, a ponto de modificar a estrutura musical e dramática da sua ópera para satisfazer os distintos apreços musicais das platéias dos teatros nos quais ele encenava suas obras. Em vista dessas circunstâncias, o compositor adaptava as suas criações para todo tipo de eventualidade. Algo muito comum também consistia no fato de que uma determinada ópera poderia receber numa dada encenação diversas interpolações de óperas de outros compositores, sem que se respeitasse o conteúdo dramático da obra original. Conforme comentam Yara Caznók e Alfredo Naffah Neto acerca dos costumes do público tradicional de ópera: "Não se ouvia a obra em sua duração total para depois percebê-la como uma. Tratava-se da vivência de pequenas e inúmeras unidades propiciadas pelos números isolados que não sem razão eram também chamados de números isolados". ${ }^{37}$ Wagner propunha então a radical transformação do gosto estético do público burguês, que deveria aprender a contemplar a obra de arte como uma necessidade vital da condição humana, de forma alguma como mero ornamento utilizado para deleite arrogante e dissimulação social. Wagner argumenta que

a moda é o estimulante artificial que desperta uma carência não-natural onde a carência natural não existe: porém, aquilo que não decorre de uma carência real é arbitrário, incondicionado, tirânico. A moda é, por isso, a mais inaudita, a mais louca tirania que alguma vez foi produzida pela perversão da essência humana: da natureza ela exige 
obediência absoluta; às carências reais impõe a mais completa auto-denegação em favor de carências imaginárias; no homem, ela obriga o natural sentido da beleza à adoração do feio; liquida-lhe a saúde para Ihe ensinar o gosto pela doença; quebra-lhe o vigor e a força para o fazer sentir conforto nas suas fraquezas. Onde dominar a moda mais ridícula, aí a natureza terá que ser vista como a coisa mais ridícula; onde dominar a mais criminosa anti-natureza, aí a expressão da natureza surgirá como supremo crime; onde a loucura conquista o lugar da verdade, aí a verdade será declarada louca e posta atrás das grades. ${ }^{38}$

Nasce daí o projeto wagneriano de criação de um novo modelo de teatro no qual somente o artista efetivamente comprometido com a obra de arte poderia exercer o seu poder e voz de comando. Eis a explicação para Bayreuth, considerado um local no qual a música e as artes seriam celebradas como um ofício sagrado, livre do olhar vazio dos profanos. De acordo com Henry Burnett, "o novo sentido da música está ligado, portanto, com uma identificação entre a educação do público, uma nova configuração política e, principalmente, um novo olhar sobre a música, o qual, em Bayreuth, é sinônimo da própria vida reencontrada". ${ }^{39}$ A proposta original que Wagner destinava para Bayreuth consistia em apresentar um drama musical direcionado para a apreciação de um público artista, como uma consagração musical após uma intensa jornada de luta em prol da afirmação da cultura, possibilitando uma interação universal entre os homens de gênio através do amor pela arte libertadora. É importante destacar que, antes de seu rompimento com Wagner, Nietzsche percebia a existência de um poder esteticamente transfigurador neste novo modelo de teatro:

Bayreuth significa para nós a manhã de consagração no dia da batalha. Não se poderia fazer pior injustiça do que supor que, para nós, trata-se unicamente da arte: como se a arte fosse um remédio ou narcótico, graças ao qual fosse possível se desfazer de todas as misérias. Vemos na imagem da obra de arte trágica de Bayreuth justamente a luta dos indivíduos contra tudo o que se apresenta como uma necessidade aparentemente inexorável: contra o poder, a lei, a tradição, a convenção e toda ordem estabelecida das coisas. ${ }^{40}$

Entretanto, ao assistir às encenações do Festival de Bayreuth, Nietzsche se desaponta com Wagner, que teria se desvirtuado dos seus projetos originais ao condescender com a satisfação do público. Onde estava a celebração artística que outrora o compositor propunha para a revitalização da cultura germânica, na qual os valores decadentistas seriam contestados em prol da afirmação da criatividade do gênio artístico, no embate contra os poderes instituídos e legitimados pelos códigos morais conservadores de uma classe detentora dos recursos econômicos da sociedade, incapaz de apreciar a beleza de uma obra de arte? Para Nietzsche, em Bayreuth se é honesto apenas como massa, o indivíduo renuncia ao direito de ter a própria escolha, ao direito a seu gosto. ${ }^{41} \mathrm{Em}$ Bayreuth ocorre justamente a negação dos ideais revigorantes da cultura, pela presença determinante de um público ruidoso e pedante, ávido pela satisfação de seus apetites hedonistas, cujo comportamento vulgar em relação à fruição da obra de arte se assemelhava ao dos "filisteus da cultura" pela incapacidade de compreenderem o genuíno sentido da criação artística. ${ }^{42}$ Analisando essa polêmica, Fischer-Dieskau 
enuncia a seguinte pergunta retórica: "A questão decisiva era esta: Arte no sentido da tragédia antiga ou teatro moderno obedecendo às exigências do dia?" ${ }^{43}$

Nietzsche considera que na obra de Wagner os instintos vitais e a apreciação da arte trágica são pervertidos e transformados em histeria dos afetos, e o contato imediato do indivíduo enquanto artista com a essência primordial do trágico avilta-se em arte franqueada para o gozo desenfreado de uma massa turbulenta - justamente os sintomas de declínio cultural que o filósofo combatia tão ardorosamente na sua defesa do projeto wagneriano. Desse modo, Nietzsche considera que Wagner, na última fase de sua produção musical, subverteu o seu próprio ideal estético da música como o elemento sintetizador de todas as artes, ao considerar a ópera como meio de expressão para conceitos e não como um fim estético, tornando a música uma serva das teorias ascéticas e morais vinculadas ao drama operístico. Conforme os esclarecimentos de Rosa Maria Dias,

a crítica de Nietzsche ao romantismo wagneriano nos faz ver o drama musical deste compositor como fruto de uma dupla impotência: de estilo, porque a música foi sacrificada à idéia, e de existência, porque o drama foi criado para compensar uma falta. $^{44}$

Destaquemos também a questão do uso das orquestrações monumentais, dominadas pelo naipe dos metais, como forma de embotar no ouvinte uma percepção musical contínua e o sentimento de arrebatamento diante da massa sonora, pois o timbre dos metais, em decorrência de seu volume, tende a superar todo o conjunto da orquestra. Quais os efeitos "fisiológicos" de todo esse procedimento estético empreendido por Wagner? Nietzsche considera que essa técnica de orquestração seria um recurso wagneriano utilizado para seduzir o espectador, através da geração de intensas impressões estéticas, que elevaria os múltiplos estados afetivos do ouvinte à custa, todavia, da própria degenerescência vital daquele, pois esse processo exige o direcionamento do fluxo nervoso para a concentração da mente diante da percepção audiovisual da ópera wagneriana. A orquestração wagneriana é considerada como de "difícil digestão", isto é, ela causa transtornos nervosos, um incômodo orgânico para aquele que se aventura a apreciá-la. ${ }^{45}$ Eis o motivo pelo qual Nietzsche considera Wagner como um hipnotizador, um grande manipulador de afetos, cujo objetivo seria justamente o de conceder ao ouvinte esse sensacionalismo estético mediante o uso de recursos histriônicos, uma negação da percepção artística comprometida com o acréscimo de potência vital. ${ }^{46} \mathrm{Com}$ efeito, a metamorfose geral da arte em histrionismo é uma expressão de degenerescência fisiológica, uma forma de histerismo ${ }^{47}$ Nietzsche diz que

Wagner não era músico por instinto. Ele o demonstra ao abandonar toda lei e, mais precisamente, todo estilo na música, para dela fazer o que ele necessitava, uma retórica teatral, um instrumento de expressão, do reforço dos gestos, do sujeito, do psicológicopitoresco. ${ }^{48}$ 
Podemos considerar que o grande problema desse procedimento consiste na necessidade de se gerar o contínuo processo de elaboração de estímulos estéticos fortes, como forma de se agradar aos apelos de uma afetividade tensa e uma organicidade degenerada. Nietzsche identifica nesta tendência um processo de declínio fisiológico, típico da cultura moderna, pois a busca por sucessivas experimentações intensas é um sinal de adoecimento nervoso, decorrente de transtornos do funcionamento saudável do corpo. ${ }^{49} \mathrm{Um}$ organismo constituído de maneira saudável se caracteriza pela capacidade de assimilar sem maiores transtornos as impressões recolhidas mediante contato com a realidade circundante, pois o pleno funcionamento das atividades orgânicas processa satisfatoriamente essas impressões afetivas, sem deixar que estas prejudiquem o bem-estar do psiquismo individual.

$\mathrm{Na}$ interpretação fisiológica da arte, podemos considerar então que a música de Wagner decorre diretamente desse empobrecimento dos instintos vitais, da incapacidade de se expressar a qualidade da saúde e da força mediante a interação com a obra de arte. Pelo contrário, o que se busca, na verdade, é a agitação dos processos fisiológicos do corpo, situação que gera uma espécie de adoecimento individual. ${ }^{50} \mathrm{~A}$ música de Wagner, segundo Nietzsche, é um poderoso excitante dos nervos doentes, pois o seu propósito estético seria o de motivar uma profusão de estados de tensão na afetividade do espectador das suas obras. ${ }^{51} \mathrm{O}$ personagem wagneriano é frágil organicamente, decadente psicofisicamente, sendo incapaz de superar as suas adversidades cotidianas, pois o transbordamento das suas forças vitais the é intrinsecamente estranho, situação que retrata o âmago da arte moderna, expressão do declínio biológico. Wagner resumiria em sua obra essa tendência doentia, adornando-a com os recursos decadentes da moral. Para Nietzsche,

nada existe de mais cansado, de caduco, de vitalmente perigoso e de caluniador do mundo, entre as coisas do espírito, que a sua arte não tenha secretamente tomado em sua proteção - é o negro obscurantismo, o que ele esconde nos mantos de luz do ideal. Ele incensa todo instinto niilista (budista), e o transveste em música, ele incensa todo Cristianismo, toda forma de expressão religiosa da décadence. ${ }^{52}$

A música wagneriana perde assim o seu outrora postulado caráter trágico, o seu poder de concretizar $o$ ato da transfiguração existencial da condição individual em um fenômeno estético que concede ao indivíduo a força e a saúde:

De que sofro, quando padeço o destino da música? Ressinto-me de que a música tenha sido privada de seu caráter afirmativo e transfigurador do mundo, que tenha se tornado música de decadência, não sendo mais a flauta de Dionísio. ${ }^{53}$

Desse modo, Wagner encerra a sua criação artística demonstrando a suma exaltação dos ideais considerados por Nietzsche como niilistas, os valores cristãos e budistas, sintetizados na sua ópera Parsifal. Para Nietzsche, uma obra da imponência de Parsifal, 
composta por um Wagner que estava no ápice de sua atividade criativa, utilizando um elevado refinamento estético para propagar valores decadentes, como o ascetismo radical e a piedade por tudo aquilo que é fraco, ou para reforçar as esperanças na existência de mundo imaterial idealizado, seria uma perversão cultural. Wagner diluía as suas próprias habilidades de compositor genial, renegando as suas revolucionárias propostas artísticas pessoais em prol de um ideal conservador, afirmando assim a vitória do ideal ascético instaurado pelo racionalismo exacerbado do pensamento socráticoplatônico e consumado pela moralidade cristã. Com efeito, se Wagner fora considerado outrora o gênio que restauraria a cultura trágica dos gregos, a sua guinada ascética na verdade demonstraria a sua adesão ao espírito desvitalizado que impera na civilização ocidental na confluência de platonismo e Cristianismo, em que Wagner se torna o representante moderno desta disposição existencial da fraqueza. Conforme pondera Nietzsche:

Quem não desejaria, em consideração ao próprio Wagner, que ele houvesse se despedido de nós e de sua arte de outro modo, não com um Parsifal, e sim mais vitorioso, mais seguro de si, mais wagneriano, menos enganador, menos schopenhaueriano, menos niilista ${ }^{54}$

Tratava-se da derrocada cabal dos antigos valores de força e saúde como modelos de virtude, conceitos tão caros ao espírito trágico dos gregos em prol da instauração de um código moral caracteristicamente repressor da genialidade individual dos homens criadores que proporcionam com suas vidas e obras a exaltação da própria existência. Para Iracema Macedo, no entendimento de Nietzsche, Wagner, ainda que tenha pensado muito em chegar a um ideal de vida forte e bela, não atingiu em sua arte o caráter afirmativo da arte grega. ${ }^{55}$

Nietzsche, na "Tentativa de autocrítica" de O nascimento da tragédia, realiza uma espécie de revisão do seu vínculo de outrora com o ideal romântico de Wagner e com a filosofia schopenhaueriana, enfatizando os motivos que o levaram a se emancipar intelectualmente e afetivamente dessas duas grandes referências:

[...] toda a vida repousa sobre a aparência, a arte, a ilusão, a óptica, a necessidade do perspectivismo e do erro. O Cristianismo foi desde o inicio, essencial e basicamente, asco e fastio da vida na vida, que apenas se disfarçava, apenas se ocultava, apenas se enfeitava sob a crença em "outra" ou "melhor" vida. O ódio ao "mundo", a maldição dos afetos, o medo à beleza e à sensualidade, um "lado-de-lá" inventado para difamar melhor o "lado-de-cá", no fundo um anseio pelo nada, pelo fim, pelo repouso, para chegar ao "sabá dos sabás" [...]. ${ }^{56}$

Tanto Wagner como Schopenhauer seriam representantes da decadência fisiológica, do enfraquecimento da vitalidade, de onde decorreria a manifestação dos valores pessimistas nas suas obras e o projeto de redenção da existência através da negação dos instintos corporais. Nietzsche denomina esse modelo valorativo de "pessimismo romântico", pois nessa tendência se postula a renúncia ao caráter trágico do mundo, em prol da legitimação dos estados de passividade, de quietude, da busca pela remissão 
eterna. O corpo e a sensibilidade são vistos como elementos que fazem o ser humano sofrer continuamente, daí a necessidade do afastamento dessa dimensão material. $O$ "pessimismo romântico" proporia também uma espécie de embriaguez, mas uma embriaguez "narcótica" que atua psicologicamente como fuga existencial da realidade, pois esta se apresenta marcada pelo sofrimento, sendo assim imputada como miserável. A aplicação estética dessa disposição fisiológica degenerada seria justamente um personagem cansado, assolado pelo tédio, que vislumbra a redenção espiritual ou mesmo social como estado existencial de libertação das dores da vida. ${ }^{57}$ É importante destacarmos que em $\mathrm{O}$ nascimento da tragédia já existe uma contraposição entre o "pessimismo dionisíaco" e o "otimismo racionalista" a partir da idéia do declínio da cultura trágica dos gregos, processo de dissolução dos valores afirmativos do existir que teria sido efetivada pelo socratismo-platonismo e pela estética racionalista da tragédia empregada por Eurípides ${ }^{58}$ Essa visão de mundo considera que o fundamento do existir humano consiste na busca incessante pela luz da razão e pela consciência, desvalorizando tudo aquilo que é realizado de forma instintiva, desprovido dessa fria lógica racional, pois somente o que é inteligível pode ser imputado como belo. ${ }^{59}$ Nietzsche se indagaria: que circunstância motivaria essa busca incondicional pela consciência, pela verdade racional, à custa da saúde dos instintos e da afetividade? Trata-se da manifestação do estado de declínio fisiológico do corpo, pois a perspectiva otimista da existência, segundo a qual podemos alcançar a "verdade" através da racionalidade e da consciência desvinculada da afetividade, denota um enfraquecimento dos instintos vitais. A razão que se expande anômala luta contra os instintos e os enfraquece. Perturba-se com isso a cooperação orgânica das funções fisiológicas É a partir dessa conjuntura de condições que surge o homem teórico, a figura que realiza um violento divórcio entre o conhecimento e a vida. ${ }^{60}$ Müller-Lauter esclarece que

não é apenas nos modernos que o filósofo deve poder constatar os fenômenos psicológicos, e por fim os fisiológicos, de declínio. A própria filosofia já está, desde Sócrates, na via da perversão. O esquema de interpretação, que se confirma no que diz respeito à décadence artística de Wagner, deve também ajudar a desmascarar a décadence filosófica dos gregos. ${ }^{61}$

A crença otimista no valor absoluto da verdade e da racionalidade como instâncias superiores da condição humana são também sintomas de declínio fisiológico dos seus ideólogos, pois por meio dessa proposta busca-se a negação da importância instintiva do corpo e da vida, em prol de um estado ideal de existência, calcado numa suposta dimensão abstrata. Por isso Nietzsche enfatiza com tanta veemência, nas suas críticas ao modelo de vida preconizado por Sócrates, o fato de este ter no momento derradeiro de sua existência, tal como relatado no Fédon, afirmado veladamente aos seus discípulos a idéia de que a vida corporal é um grande erro, uma doença, e que somente a morte, considerada como a redentora libertação da alma, pode curar de forma definitiva:

Sócrates moribundo - Eu admiro a bravura e a sabedoria de Sócrates em tudo o que ele fez, disse - e não disse. Esse zombeteiro e enamorado monstro e aliciador ateniense, 
que fazia os mais arrogantes jovens tremerem e soluçarem, foi não apenas o mais sábio tagarela que já houve: ele foi igualmente grande no silêncio. Quisera que também no último instante da vida ele tivesse guardado silêncio - nesse caso, ele pertenceria talvez a uma ordem de espíritos ainda mais elevada. Terá sido a morte, ou o veneno, ou a piedade, ou a malícia - alguma coisa lhe desatou naquele instante a língua, e ele falou: "Oh, Críton, devo um galo a Asclépio". Essa ridícula e terrível "última palavra" quer dizer, para aqueles que têm ouvidos: "Oh, Críton, a vida é uma doença!" Será possível? Um homem como ele, que viveu jovialmente e como um soldado à vista de todos - era um pessimista? Ele havia feito uma cara boa para a vida, o tempo inteiro ocultando o seu último juízo, seu íntimo sentimento! Sócrates, Sócrates sofreu da vida! E ainda vingouse disso - com essas palavras veladas, horríveis, piedosas e blasfemas! Também Sócrates necessitou de vingança? Faltou um grão de generosidade à sua tão rica virtude? - Ah, meus amigos, nós temos que superar também os gregos!"62

Para Nietzsche, Sócrates também sofreu da decadência dos instintos vitais, pois ele buscou a sua morte a todo custo, pois via nesta o passaporte para uma postulada realidade "melhor", na qual poderia contemplar adequadamente as Idéias imutáveis. ${ }^{63}$ Por qual motivo Sócrates não deprecia a morte, mas antes se esforça para efetivá-la? Pelo fato de que ele considera conhecer adequadamente aquilo que virá no além da vida física, de forma ainda mais nítida do que o mundo físico no qual ele até então vivera. Afinal, o mundo terreno está sujeito ao vir-a-ser, onde nada pode ser considerado fixo e perfeito. Esse mundo físico é apenas destinado ao uso dos sentidos, aos aspectos vulgares do ser humano. Para aquele que vislumbra obter a plena felicidade, deve-se abdicar dessa realidade fenomênica, ilusória. Portanto, para que se possa conhecer o mundo abstrato, a dimensão espiritual, deve-se fechar os olhos físicos e abrir os olhos da alma, contemplar a realidade verdadeira que se encontra para além das inúmeras miragens físicas. Para tanto, é necessário que o investigador da verdade tenha a capacidade de depurar tudo aquilo que lhe é transmitido pelo uso dos sentidos, afirmando apenas a sua pretensa racionalidade pura, abstrata.

Pensando de acordo com Nietzsche, esse procedimento decorreria de um grande erro de interpretação do valor da vida e do corpo, denotando o enfraquecimento dos instintos corporais, do próprio funcionamento normal do processo fisiológico do corpo. "Existe algo errado no corpo, pois ele sofre e se corrompe, logo, ele é o grande responsável pela minha decadência", assim pensa o apologeta do ideal ascético que deprecia a existência física e a vida sensual. A história da cultura ocidental redigida a partir do platonismo e da moral cristã seria a expressão do declínio fisiológico da humanidade, pois os valores que se afirmaram ao longo de dois milênios foram o da ascese, da renúncia ao corpo e da busca incessante pela vida teórica, ainda que em detrimento da dinâmica da realidade em que vivemos. Nietzsche enuncia no Prólogo de Além do bem e do mal a sentença de que o "Cristianismo é um platonismo para o povo" ${ }^{4}$, isto é, a sua vulgarização por excelência, pois a moralidade cristã nada mais faz do que dar continuidade aos parâmetros metafísicos estabelecidos séculos antes por Platão na sua divisão da realidade entre sensível e inteligível. Portanto, do platonismo ao idealismo romântico, existe uma grande linha contínua, pois ambos anseiam pela estabilidade e perfeição plena das condições de vida, somente possíveis numa suposta esfera espiritual. Para 
tanto, torna-se necessária a negação das particularidades imanentes do existir. Em decorrência desses motivos, Nietzsche proclama a elaboração do "pessimismo trágico/dionisíaco", que expressa uma gratidão e um amor pelo existir. ${ }^{65}$ Nessa visão de mundo, o sofrimento e a destruição são reconhecidos como elementos indissociáveis do existir, mas, ao invés de se propor a fuga desses elementos, legitima-se a afirmação desses estados, inclusive os mais contraditórios para a manutenção da vida individual. Tudo aquilo que existe é digno de ser glorificado.

No "pessimismo trágico", não se pressupõe a aceitação do devir, pois aceitar não é uma atitude plena, mas uma espécie de passividade consciente. Acima de tudo é necessário que se afirme a dor, a destruição e a morte, tornando esses elementos intrínsecos ao âmbito da vida, e a arte cumpre esse papel de divinização da existência. Segundo Santiago-Guervós, a arte há de estar sempre a serviço da vida, para transfigurá-la e fazê-la mais bela, pois a vida e o sofrimento são elementos indissociáveis, porque não é possível eliminar a dor consubstancial à natureza do homem. ${ }^{66}$ Essa é a característica primordial do "pessimismo trágico", o reconhecimento e enfrentamento da realidade, através de uma axiologia estética desprovida de traços moralizantes e transcendentes.

Podemos então distinguir dois grandes tipos de pessimismos, tal como enunciados por Nietzsche: um da força, que afirma as condições de saúde, a busca por desafios e a interação mesmo com as circunstâncias mais desfavoráveis do existir; outro da fraqueza, que apresenta o declínio das capacidades fisiológicas de assimilação das vivências da realidade, decorrendo dessa deficiência a negação do valor intrínseco da vida. O "pessimismo trágico/dionisíaco" encarna os valores de uma atividade fisiológica saudável, que assimila as vivências cotidianas sem permitir a aparição de estados ressentidos na afetividade, pois exalta a idéia de que tudo aquilo que existe é digno de ser afirmado. Podemos encontrar um vínculo entre essa citada perspectiva e a idéia do amor fati, que preconiza a afirmação incondicional de todas as condições de vida, mesmo as mais dolorosas. Conforme destaca Nietzsche: "Minha fórmula para a grandeza do homem é amor fati: nada querer diferente, seja para trás, seja para frente, seja em toda a eternidade. Não apenas suportar o necessário, menos ainda ocultá-lo todo idealismo é mendacidade ante o necessário - mas amá-lo..." ${ }^{67}$

Após a decepção com a postulada "revolução estética" de Wagner, Nietzsche vislumbra na Carmen de Bizet uma possível afirmação dos valores trágicos e da cultura da força, que acreditava existir na obra wagneriana. Nesta ópera, Nietzsche percebe a valorização imanente e sensual da vida, sem que haja a intervenção de fatores metafísicos como maneira de se propor uma pedagogia essencialmente apologista dos valores morais, numa exposição de atos virtuosos tendo em vista a educação moral do público e o reforço das suas disposições ascéticas. O que se pode evidenciar na Carmen logo após a audição dos primeiros compassos da abertura é um tonificante sentimento de afirmação sensual da vida, onde prazer e dor, vida e morte, amor e ódio adquirem o 
patamar de estados afetivos indissociáveis, complementares entre si. Ao comentar a riqueza musical da obra, Nietzsche diz que

\begin{abstract}
essa música me parece perfeita. Aproxima-se leve, sutil, com polidez. É amável, não transpira. "O que é bom é leve, todo divino se move com pés delicados": primeira sentença de minha estética. Esta música é maliciosa, refinada, fatalista: no entanto, permanece popular - ela tem o refinamento de uma raça, não de um indivíduo. É rica. É precisa. Constrói, organiza, conclui: assim, é o contrário do pólipo da música, a melodia infinita. ${ }^{68}$
\end{abstract}

Se, do ponto de vista teórico, o conjunto das óperas de Wagner apresenta o conflito entre o amor carnal e o amor espiritual (com a vitória deste), até desembocar no embate final das forças do "Bem" contra o "Mal" em Parsifal, sendo assim a apologia dos valores negadores da vitalidade natural da existência humana, submetendo ainda a potência da música aos caracteres dramáticos e ao abuso dos recursos cenográficos, a música de Bizet é de certo modo esteticamente inovadora pela valorização da tragicidade imanente à existência, por ousar ser sensual; mesmo que a estrutura harmônica e dramática de Carmen seja imputada como extremamente convencional, sob o ponto de vista estético esta obra apresenta, no entanto, a possibilidade de se vencer o idealismo romântico através do renascimento do instinto trágico, e sua estrutura dramática e musical, ainda que organizada de acordo com os padrões tradicionais, supera o próprio formalismo teórico, expressando-se como uma música viva, dançante, celebratória, incandescente, que brota do âmago da terra, tal como a vitalidade dionisíaca que vivifica todos os seres, tornando-os obra de arte. ${ }^{69}$ Nietzsche, ao compreender Carmen como uma ópera de disposição organicamente saudável, leva em consideração os efeitos fisiológicos produzidos pela audição desta ópera, analisando se essa experiência estética propicia o florescimento de afetos tônicos no espectador, proporcionando assim um sentimento de leveza, alegria e um impulso de afirmação da vida. ${ }^{70}$ Trata-se de uma musicalidade que evoca a dança, a embriaguez da potência. ${ }^{71}$ Ao constatar a presença destes elementos amplificadores da vitalidade orgânica, Nietzsche considerou esta ópera como um tônico estético, um inestimável fortificante para o crescente desenvolvimento da saúde orgânica:

Também essa obra redime; não apenas Wagner é um "redentor". Com ela despedimonos do Norte úmido, de todos os vapores do ideal wagneriano. A ação já redime. De Merimée $^{72}$ ainda possui a lógica na paixão, a linha mais curta, a dura necessidade. [...] Em todo aspecto o clima muda. Aqui fala uma outra sensualidade, uma outra sensibilidade, uma outra serena alegria. Essa música é alegre, mas não de uma alegria francesa ou alemã. Sua alegria é africana; ela tem a fatalidade sobre si, sua felicidade é curta, repentina, sem perdão. Invejo Bizet por isso, por haver tido a coragem para essa sensibilidade, que até então não teve idioma na música cultivada da Europa - esta sensibilidade mais morena, mais queimada... ${ }^{73}$

Em suma, o critério maior para a avaliação do efeito proporcionado pela música no organismo humano é especificamente fisiológico. Todavia, uma questão que deve ser 
destacada é que uma compreensão fisiológica da arte jamais pode partir de pressupostos universalistas. Desse modo, é Nietzsche quem efetivamente experimenta uma fruição saudável e alegre pela audição de Carmen, da mesma maneira que o Parsifal de Wagner pode também motivar uma elevação tônica nas disposições vitais de um dado ouvinte. Cada organismo, mediante sua interação com uma criação artística, pode vir a desenvolver reações afetivas que talvez em outrem sejam distintas. Tal circunstância, todavia, não desqualifica do modo algum a "fisiologia da arte" de Nietzsche, pois ela parte de um projeto estético que valoriza para cada organismo a recepção de uma espécie de estímulos que poderão ou não intensificar a sua vitalidade, destacando-se assim da perspectiva transcendental da fruição estética, tão distante de uma genuína compreensão das atividades orgânicas do corpo humano.

\section{* Renato Bittencourt é doutor em filosofia pela UFRJ/PPGF.}

1 Algumas obras de referência para a compreensão da idéia de fisiologia no pensamento nietzschiano são as de MÜLLER-LAUTER, W. "Décadence artística enquanto décadence fisiológica. A propósito da crítica tardia de Friedrich Nietzsche a Richard Wagner". Tradução de Scarlett Marton. Cadernos Nietzsche, n. 6, 1999, pp. 11-30, em especial pp. 21-22; HEIDEGGER, M. Nietzsche, I. Tradução de Marco Antonio Casanova. Rio de Janeiro: Forense, 2007, em especial pp. 84-98; STIEGLER, B. Nietzsche et la biologie. Paris: PUF, 2001; FREZZATTI JR, W. A. A fisiologia de Nietzsche: a superação da dualidade cultura/biologia. ljuí: Unijuí, 2006, assim como RIBEIRO, M. S. Vida e liberdade: a psicofisiologia de Nietzsche. Londrina: UEL, 1999.

${ }^{2}$ NIETZSCHE, F. A gaia ciência, Tradução de Paulo César de Souza. São Paulo: Companhia das Letras, 2003, § 368, pp. 270-271; Idem. O caso Wagner: um problema para músicos; Nietzsche contra Wagner - Dossiê de um Psicólogo. Tradução de Paulo César de Souza. São Paulo: Companhia das Letras, 1999. "No que faço objeções", p. 53.

${ }^{3}$ Idem, O caso Wagner. Op. cit., § 1, p. 12.

${ }^{4}$ DIAS, R. M. Nietzsche e a música. Rio de Janeiro: Imago, 1994, p. 119.

${ }^{5}$ NIETZSCHE, F. Nietzsche contra Wagner, "No que faço objeções”, p. 12.

6 NIETZSCHE, F. Genealogia da moral. Tradução de Paulo César de Souza. São Paulo: Companhia das Letras, 1999, III, § 6, pp. 93-95.

${ }^{7}$ MÜLLER-LAUTER, W. Op. cit., p. 17.

${ }^{8}$ NIETZSCHE, F. Genealogia da moral. Op. cit., III, § 6, pp. 93-95.

${ }^{9}$ KANT, I. Crítica da faculdade do juízo, Tradução de António Marques e Valério Rohden. Rio de Janeiro: Forense Universitária, 2002, "Analítica do Belo", § 6, p. 56.

10 SCHOPENHAUER, A. O mundo como vontade e como representação. Tradução de Jair Barboza. São Paulo: EDUSP, 2005, III, § 38, pp. 266-268.

${ }^{11}$ Ibidem, III, § 40, pp. 280-282.

12 SCHOPENHAUER, A. Metafísica do belo. Tradução de Jair Barboza. São Paulo: UNESP, 2003, Cap. 6, "Do Gênio", p. 61.

${ }^{13}$ NIETZSCHE, F. Genealogia da moral. Op. cit., III, § 6, pp. 94-95. 
14 STENDHAL. Do amor. Tradução de Roberto Leal Ferreira. São Paulo: Martins Fontes, 1999, Cap. XVII, nota 33, p. 34

${ }^{15}$ NIETZSCHE, F. Genealogia da moral. Op. cit., III, § 7, p. 97.

${ }^{16}$ Ibidem, § 6, p. 94.

17 NIETZSCHE, F. Crepúsculo dos ídolos ou como filosofar com o martelo. Tradução de Marco Antônio Casanova. Rio de Janeiro: Relume Dumará, 2000, "Incursões de um extemporâneo", § 8 , p. 70.

${ }^{18}$ Ibidem.

${ }^{19}$ NIETZSCHE, F. Genealogia da moral. Op. cit., II, § 1, p. 47-48

${ }^{20}$ DIAS, R. M. "Nietzsche e a fisiologia da arte" In: Revista de Filosofia SEAF, n. 4, 2004, pp. 6577 , aqui p. 67.

${ }^{21}$ Para esclarecimentos sobre a relação de Wagner com a valoração romântica e suas tendências pessimistas, ver HOLLINRAKE, R. Nietzsche, Wagner e a filosofia do pessimismo. Tradução de Álvaro Cabral. Rio de Janeiro: Jorge Zahar, 1986.

${ }^{22}$ NIETZSCHE, F. Genealogia da moral. Op. cit., III, § 2, p. 88.

${ }^{23}$ Iracema Macedo analisa as semelhanças arquetípicas entre os mitos gregos e as narrativas wagnerianas de O navio fantasma, Tannhäuser e Lohengrin, demonstrando que, apesar da roupagem cristianizada que o compositor concede a esses mitos em suas óperas, tais adaptações de forma alguma retirariam a intensidade trágica de tais temas, justamente pela sua origem pagã. Cf. MACEDO, I. Nietzsche, Wagner e a época trágica dos gregos. São Paulo: Annablume, 2006, pp. 87-95.

${ }^{24}$ WAGNER, R. A arte e a revolução. Tradução de José M. Justo. Lisboa: Antígona, 1990, § 3, p. 48.

${ }^{25}$ NIETZSCHE, F. Nietzsche contra Wagner. Op. cit., "Wagner como apóstolo da castidade", § 3, p. 65.

${ }^{26}$ NIETZSCHE, F. Genealogia da moral. Op. cit., III, § 3, p. 90; Nietzsche contra Wagner. Op. cit., "Wagner como apóstolo da castidade", § 3, p. 65. Destaquemos que a idéia de "sensualidade sadia" decorre da influência de Feuerbach sobre Wagner, Para mais detalhes, FEUERBACH, L. Princípios da filosofia do futuro. Tradução de Artur Morão. Lisboa: Ed. 70, 2002.

${ }^{27}$ MACEDO, I. Nietzsche, Wagner e a época trágica dos gregos. Op. cit., p. 100.

28 Ibidem, p. 38.

${ }^{29}$ NIETZSCHE, F. O anticristo. Tradução de Artur Morão. Lisboa: Ed. 70, 1997, "Lei contra o Cristianismo, IV Proposição", p. 106.

${ }^{30}$ NIETZSCHE, F. Genealogia da moral. Op. cit., III, § 8, p. 101.

${ }^{31}$ DIAS, R. M. "Nietzsche e a fisiologia da arte". Op. cit., p.71

${ }^{32}$ NIETZSCHE, F. O caso Wagner. Op. cit., § 3, p. 14.

${ }^{33}$ Ibidem, § 7, pp. 22-23.

34 Ibidem, § 5, p. 19.

${ }^{35}$ BARROS, F. O pensamento musical de Nietzsche. São Paulo: Perspectiva, 2007, p. 133.

${ }^{36}$ WAGNER, R. A arte e a revolução. Op. cit., § 4, p. 59. 
${ }^{37}$ CAZNOK, Y. B.; NAFFAH NETO, A. Ouvir Wagner - Ecos nietzschianos. São Paulo: Musa, 2000, p. 24.

${ }^{38}$ WAGNER, R. A obra de arte do futuro. Trad. de José M. Justo. Lisboa: Antígona, 2003, pp. 3132.

${ }^{39}$ BURNETT, H. “Nietzsche em Bayreuth”. In: Discurso, n. 37, 2007, pp. 217-259, aqui p. 239.

${ }^{40}$ NIETZSCHE, Wagner em Bayreuth. Trad. de Anna Hartmann Cavalcanti. Rio de Janeiro: Jorge Zahar, 2009, § 4, p. 65.

${ }^{41}$ Idem, Nietzsche contra Wagner, "No que faço objeções", p. 54.

${ }^{42}$ Para uma contextualização dessa polêmica, remeto aos esclarecedores textos de DIAS, R. M. "Nietzsche e o caso Wagner" In: AZEREDO, V. D. (org.) Falando de Nietzsche. ljuí: Ed. Unijuí, 2005, pp. 23-40; e "Nietzsche e Wagner: amizade de astros". In: BARRENECHEA, M. A.; FEITOSA, C (orgs.) Assim falou Nietzsche II. Rio de Janeiro: Relume Dumará, 2000, pp. 117-132.

${ }^{43}$ FISCHER-DIESKAU, D. Wagner y Nietzsche: El Mistagogo y su apóstata. Tradução de Vicente Romano. Madrid: Altalena, 1982, p. 147.

${ }^{44}$ DIAS, R. M. Nietzsche e a música. Op. cit., p. 118.

${ }^{45}$ NIETZSCHE, F. O caso Wagner. Op. cit., $§ 1$, p. 11.

${ }^{46}$ Ibidem, § 5, p. 19.

${ }^{47}$ Ibidem, § 7, p. 22.

${ }^{48}$ Ibidem, § 8, p. 25.

49 Ibidem, § 8, p. 25.

${ }^{50}$ Ibidem, § 5, p. 18.

51 Ibidem, § 5, p. 19.

52 Ibidem, "Pós-Escrito", p. 36.

${ }^{53}$ NIETZSCHE, F. Ecce Homo. Como alguém se torna o que se é. Tradução de Paulo César de Souza. São Paulo: Companhia das Letras, 2001, “O Caso Wagner” § 1, pp. 102-103.

${ }^{54}$ NIETZSCHE, F. Genealogia da moral. Op. cit., III, § 4, p. 91.

${ }^{55}$ MACEDO, I. Nietzsche, Wagner e a época trágica dos gregos. Op. cit., p.190.

${ }^{56}$ NIETZSCHE, F. O nascimento da tragédia. Tradução de J. Guinsburg. São Paulo: Companhia das Letras, 1996, "Tentativa de autocrítica”, § 5, p. 19.

${ }^{57}$ NIETZSCHE, F. A gaia ciência. Op. cit., § 370.

${ }^{58}$ NIETZSCHE, F. O nascimento da tragédia. Op. cit., § 10, p. 72.

${ }^{59}$ Ibidem, § 12, p. 79-83.

${ }^{60}$ Ibidem, § 15, p. 92-93

${ }^{61}$ MÜLLER-LAUTER, W. "Décadence artística enquanto décadence fisiológica. A propósito da crítica tardia de Friedrich Nietzsche a Richard Wagner". Op. cit., p. 18.

${ }^{62}$ NIETZSCHE, F. A gaia ciência. Op. cit., § 340, pp. 229-230; PLATÃO. Fédon. Tradução de Maria Teresa Schiappa de Azevedo. Brasília: UnB, 2000, 118a.

${ }^{63}$ NIETZSCHE, F. Crepúsculo dos ídolos. Op. cit., "O Problema de Sócrates”, § 1, p. 17.

${ }^{64}$ NIETZSCHE, F. Além do bem e do mal. Tradução de Paulo César de Souza. São Paulo: Companhia das Letras, 2000, "Prólogo", p. 8.

${ }^{65}$ NIETZSCHE, F. A gaia ciência. Op. cit., § 370, pp. 272-274. 
66 SANTIAgO GUERVÓS, L. E. de. Arte y Política: aproximación a la estética de Nietzsche. Madrid: Trotta, 2004, p. 332.

${ }^{67}$ NIETZSCHE, F. Ecce Homo. Op. cit., "Porque sou tão inteligente", § 10, p. 51.

${ }^{68}$ NIETZSCHE, F. O caso Wagner. Op. cit., § 1, p. 11.

${ }^{69}$ NIETZSCHE, F. O nascimento da tragédia. Op. cit., § 1, p. 31.

${ }^{70}$ NIETZSCHE, F. O caso Wagner. Op. cit., § 2, pp. 12-13.

${ }^{71}$ Para aprofundamento da questão do orgiasmo estético dionisíaco através da dança, destaco o texto de SANTIAGO GUERVÓS, L. E. de: "Nos limites da linguagem: Nietzsche e a expressão vital da dança". Tradução de Alexandre Filordi. In: Cadernos Nietzsche, n. 14, 2003, pp. 83-104.

72 Prosper Mérimeé, o célebre autor do romance homônimo em que Henri Meilhac e Ludovic Halévy se basearam para a elaboração do libreto da ópera Carmen, musicada por Georges Bizet.

${ }^{73}$ NIETZSCHE, F. O caso Wagner, § 2, pp. 12-13. 